\title{
Penerapan Kearifan Lokal Masyarakat Bali yang Dapat Mengurangi Stigma Terhadap Orang dengan Gangguan Jiwa
}

\author{
Ida Bagus Gde Agung Yoga Pramana dan Yohanes Kartika Herdiyanto \\ Program Studi Psikologi, Fakultas Kedokteran, Universitas Udayana \\ tugusyogapramana@gmail.com
}

\begin{abstract}
Abstrak
Hasil riset kesehatan dasar pada tahun 2013 menunjukkan bahwa prevalensi kasus gangguan jiwa dengan tipe skizofrenia di Indonesia sebesar 1,7 per seribu jumlah penduduk dan untuk prevalensi kasus gangguan jiwa tipe skizofrenia di Bali adalah sebesar 2,3 per seribu jumlah penduduk. Sebagian masyarakat Indonesia memandang gangguan jiwa dengan sudut pandang negatif atau yang biasa disebut dengan stigma. Stigma adalah bentuk prasangka yang mendeskreditkan atau menolak seseorang maupun kelompok karena individu atau kelompok yang ditolak tersebut dianggap berbeda dengan diri kita atau kebanyakan orang. Bali yang dikenal sebagai pulau yang sarat akan budaya dan memiliki kearifan lokal yang mengikat masyarakatnya. Kearifan lokal atau yang dikenal dengan istilah kearifan tradisional merupakan semua bentuk pengetahuan, keyakinan, pemahaman, dan wawasan serta adat kebiasaan atau etika yang menuntut perilaku manusia dalam kehidupan di dalam komunitas ekologis. Berbagai nilai atau kearifan lokal yang dimiliki oleh masyarakat Bali seharusnya mampu menekan stigma yang diterima oleh ODGJ di Bali karena nilai atau kearifan lokal tersebut secara langsung mengajarkan individu untuk berperilaku saling menghargai, peduli, dan menjaga keharmonisan satu sama lain, namun pada kenyataannya ODGJ di Bali masih mendapatkan stigma negatif dari lingkungan sekitar. Berdasarkan hal tersebut, penelitian ini difokuskan untuk membahas penerapan kearifan lokal masyarakat Bali yang dapat menurunkan stigma terhadap ODGJ. Penelitian ini menggunakan metode kualitatif dengan pendekatan fenomenologi. Pengambilan data dilakukan dengan menggunakan teknik wawancara dan observasi pada total tujuh responden masyarakat Bali dengan dua kategori yaitu masyarakat umum berjumlah empat responden dan tokoh agama berjumlah tiga responden. Hasil penelitian ini menunjukkan bahwa terdapat empat konsep kearifan lokal masyarakat Bali yang dapat menurunkan stigma terhadap ODGJ yaitu tat twam asi, karma phala, tri kaya parisudha dan tri pramana. Temuan lainnya menunjukkan bahwa selain dapat menurunkan stigma, konsep karma phala ternyata dapat mendorong terbentuknya stigma masyarakat Bali terhadap ODGJ.
\end{abstract}

Kata kunci: Kearifan lokal, stigma, ODGJ, masyarakat Bali.

\begin{abstract}
The result of the research of basic health in 2013 showed that the prevalence of mental disorders cases of schizophrenia in Indonesia was as much as 1.7 out of 1000 people and for the prevalence of these cases in Bali was as much as 2.3 out of 1000 people. Most of Indonesian people view mental disorders from the negative perspective which is usually called stigma. Stigma is a form of prejudice which discredits or denies a certain person or group who are considered different from most people. Bali is known for its strong culture and local wisdom that binds its people. Local wisdom, of which most people know as traditional wisdom, is all form of knowledge, beliefs, comprehension, and insights as well as custom habits or ethics which dictate the behavior of the people in their ecological community life. Various values or local wisdom held by the Balinese people should have been able to repress the stigma against the people with mental disorders in Bali because such values or local wisdom directly dictates individuals to have respectful, caring and harmonious behavior to one another, but in reality the people with mental disorders in Bali are still receiving negative stigma from their surroundings. Based on such matter, this research was focused on discussing the implementation of local wisdom of Balinese people which can reduce the stigma against the people with mental disorders. This research used qualitative method with phenomenology approach. The data collection was conducted by utilizing interview and observational techniques on seven respondents of Balinese people with two categories namely general people, with the number of four respondents and religious figures, with the number of three respondents. The result of the research showed that there were four concepts of local wisdom of Balinese people that can reduce stigma against people with mental disorders namely tat twam asi, karma phala, tri kaya parisudha and tri pramana. Other result of the research showed that aside from reducing stigma, the concept of karma phala is actually able to promote the establishment of people's stigma against people with mental disorders.
\end{abstract}

Key words: local wisdom, stigma, people with mental disorders, Balinese people 


\section{LATAR BELAKANG}

Gangguan jiwa merupakan suatu manifestasi dari penyimpangan proses berpikir, alam perasaan dan perilaku seseorang (Thong, 2011). Menurut Undang Undang Nomor 18 Tahun 2014 Tentang Kesehatan Jiwa, orang yang mengalami gangguan dalam pikiran, perilaku, dan perasaan yang termanifestasi dalam bentuk sekumpulan gejala atau perubahan perilaku yang bermakna serta dapat menimbulkan penderitaan dan hambatan dalam menjalankan fungsi orang sebagai manusia disebut dengan Orang Dengan Gangguan Jiwa (ODGJ).

Gangguan jiwa yang dialami oleh individu disebabkan oleh berbagai faktor. Darmabrata dan Nurhidayat (2003) mengungkapkan tiga faktor penyebab gangguan jiwa diantaranya adalah organobiologik yakni gangguan jiwa yang disebabkan oleh kelainan pada otak yang ditinjau dari aspek biokimiawi, faali maupun anatomi, psikoedukatif yakni gangguan jiwa yang disebabkan oleh gangguan hambatan perkembangan kepribadian, dan sosiokultural yakni gangguan jiwa yang disebabkan oleh akibat kegagalan dalam mengatasi konflik yang terjadi di dalam masyarakat.

Gangguan jiwa memiliki beberapa bentuk. Adapun bentuk gangguan jiwa menurut Thong (2011) diantaranya yaitu gangguan mental organik seperti delirium dan dimensia, gangguan psikotik seperti skizofrenia, gangguan waham dan gangguan suasana perasaan dan juga gangguan neurotik seperti gangguan cemas, depresi dan gangguan somatoform. Gangguan psikotik ditandai oleh adanya ketidakmampuan yang berat dalam menilai realitas akibat pikiran yang kacau dan salah persepsi, sedangkan gangguan neurotik ditandai dengan mengalami gejala kecemasan yang berlebihan (Thong, 2011).

Menurut hasil riset kesehatan dasar yang dilakukan oleh Badan Penelitian dan Pengembangan Kesehatan Kementerian Kesehatan Republik Indonesia (Balitbang Kemenkes RI) tahun 2013 menunjukkan bahwa seluruh provinsi di Indonesia memiliki kasus gangguan jiwa dengan prevalensi yang berbeda-beda. Kasus gangguan jiwa tertinggi di Indonesia adalah kasus gangguan jiwa tipe psikosis dan neurosis. Kasus gangguan jiwa psikosis yang terjadi di Indonesia, merujuk pada tipe skizofrenia dengan prevalensi kasus berkisar pada rentang 1,7 permil (Balitbang Kemenkes RI, 2013). Hasil riset kesehatan dasar yang dilakukan oleh Balitbang Kemenkes RI (2013) menunjukkan bahwa kasus skizofrenia tertinggi di Indonesia terjadi di daerah Yogyakarta dan Aceh dengan prevalensi 2,7 permil sedangkan kasus skizofrenia terendah terjadi di daerah Kalimantan Barat dengan prevalensi 0,7 permil. Berdasarkan hasil riset kesehatan dasar yang dilakukan oleh Balitbang Kemenkes RI (2013), Bali memiliki prevalensi kasus skizofrenia sebesar 2,3 permil yang artinya dari 1000 penduduk diantaranya terdapat 2,3 kasus skizofrenia.

Penyebab tingginya prevalensi kasus gangguan jiwa di Yogyakarta dan Aceh disebabkan oleh beberapa faktor. Subandi (dalam Anderson dan Waskita, 2015) mengungkapkan bahwa penyebab tingginya gangguan jiwa di Yogyakarta adalah tingginya persoalan terkait dengan perubahan sosial dan ekonomi yang terjadi di Yogyakarta.
Menurut data dari Dinas Kesehatan Aceh Barat (dalam Eppang, 2016) latar belakang penyebab gangguan jiwa yang terjadi di Aceh antara lain persoalan ekonomi, masalah keluarga, konflik yang terjadi Aceh dan juga tsunami.

Penyebab gangguan jiwa di Bali disebabkan oleh beberapa faktor. Menurut Darmayasa (dalam Banjarnahor, 2014) secara umum mayoritas penyebab gangguan jiwa pada masyarakat Bali akibat adanya permasalahan keluarga dan juga faktor ekonomi. Menurut data yang dikeluarkan oleh Suryani Institute for Mental Health (dalam Parama, 2015) diperkirakan terdapat 9000 orang di Bali mengalami gangguan jiwa berat atau skizofrenia. Dinas Kesehatan (Dinkes) Provinsi Bali mencatat bahwa data mengenai kasus gangguan jiwa yang terjadi dan dilaporkan kepada Dinkes Provinsi Bali yang terjadi selama tahun 2015 didominasi oleh kasus skizofrenia dan juga gangguan neurosis. Mengacu pada data yang diberikan oleh Dinkes Provinsi Bali tersebut, peneliti memfokuskan gangguan jiwa pada penelitian ini pada skizofrenia dan gangguan neurosis.

Sebagian masyarakat Indonesia memandang gangguan jiwa dengan sudut pandang negatif. Fakta ini diperoleh dari hasil penelitian yang dilakukan oleh beberapa peneliti di Indonesia yang mengkaji tentang pandangan masyarakat terhadap gangguan jiwa. Salah satu penelitian yang mengungkap pandangan negatif masyarakat indonesia terhadap gangguan jiwa adalah penelitian yang dilakukan oleh Ide (2010). Ide (2010) mengungkapkan bahwa individu dengan gangguan jiwa atau yang dikenal dengan istilah ODGJ, seakan-akan dianggap sebagai kelompok manusia yang lebih rendah martabatnya, yang dapat dijadikan sebagai bahan olok-olokan. Lebih jauh lagi penelitian yang dilakukan oleh Adilamarta (2011) semakin memperkuat kajian ilmiah terkait stigma negatif yang diberikan oleh masyarakat terhadap ODGJ. Adilamarta (2011) mengungkapkan bahwa sebagian masyarakat di kelurahan Surau Gadang wilayah kerja Puskesmas Nanggalo memiliki sikap negatif terhadap individu yang menderita gangguan jiwa dan lebih dari sebagian masyarakat di kelurahan Surau Gadang tidak mau menerima individu dengan gangguan jiwa.

Penolakan yang dilakukan oleh masyarakat terhadap ODGJ memengaruhi penerimaan keluarga terhadap ODGJ. Berita yang ditulis oleh Anna (2012) bahkan mengungkapkan bahwa stigma negatif masyarakat terhadap ODGJ memengaruhi penolakan keluarga terhadap anggota keluarga yang telah sembuh secara medis dari gangguan jiwa. Penolakan ini mengakibatkan adanya kekambuhan pada individu yang telah dinyatakan sembuh dari gangguan jiwa. Selain Anna (2012), Herdaetha (2015) juga menulis bahwa stigma negatif yang masyarakat berikan pada ODGJ menyebabkan ODGJ merasa enggan dalam bersosialisasi dengan lingkungan luar dan cenderung menghilangkan martabat dalam kehidupan ODGJ.

Stigma negatif yang dilekatkan pada ODGJ disebabkan oleh berbagai hal. Hasil penelitian Syaharia (2009) menunjukkan bahwa stigma masyarakat terhadap gangguan jiwa secara umum ditimbulkan oleh keterbatasan pemahaman masyarakat mengenai etiologi gangguan jiwa dan nilai-nilai tradisi budaya yang masih kuat berakar sehingga gangguan jiwa sering kali dikaitkan dengan kepercayaan masyarakat yang bersangkutan. 
Lebih jauh lagi, hasil penelitian yang dilakukan Syaharia (2009) mengungkapkan bahwa nilai tradisi dan budaya yang kuat terkait dengan kepercayaan terhadap gangguan jiwa menyebabkan sebagian masyarakat tidak mau terbuka dengan penjelasan yang lebih ilmiah.

Pemerintah telah melakukan berbagai upaya untuk menanggulangi berbagai kasus yang melibatkan ODGJ. Upaya yang dilakukan oleh pemerintah ditunjukkan dengan ditetapkannya Undang-Undang nomor 18 tahun 2014 tentang kesehatan jiwa. Salah satu program yang dibentuk oleh pemerintah sebagai langkah penanggulangan gangguan jiwa di Indonesia adalah program Indonesia Bebas Pasung tahun 2017 yang di koordinasikan oleh Kementerian sosial. Program penanggulangan gangguan jiwa ini melibatkan seluruh provinsi di Indonesia (Munir, 2016).

Pemerintah daerah memiliki cara tersendiri dalam menangani kasus gangguan jiwa. Beberapa langkah yang dilakukan oleh pemerintah Yogyakarta untuk menangani kasus gangguan jiwa adalah dengan mengintensifkan sosialisasi ke masyarakat dan aktif dalam memberikan pendampingan (Kusuma, 2016). Menurut artikel yang ditulis oleh Nurdin (2016), upaya yang dilakukan pemerintah daerah Aceh sebagai salah satu daerah dengan prevalensi kasus gangguan jiwa tertinggi di Indonesia adalah dengan memberikan jaminan kesehatan berupa pengobatan gratis kepada seluruh masyarakat Aceh.

Pemerintah Provinsi Bali juga memiliki beberapa upaya dalam menangani kasus gangguan jiwa. Pemerintah Provinsi Bali menunjukkan upaya penanggulangan gangguan jiwa dengan cara meringankan biaya perawatan pasien gangguan jiwa melalui program Jaminan Kesehatan Bali Mandara (JKBM) (Sutika, 2014). Mulai tanggal 1 Januari 2017, pemerintah Provinsi Bali mentransformasikan program layanan kesehatan gratis Jaminan Kesehatan Bali Mandara (JKBM) menjadi Jaminan Kesehatan Nasional (JKN) di bawah Badan Penyelenggara Jaminan Sosial (BPJS) (Muhhamad, 2015). Upaya lain yang dilakukan oleh Pemerintah Provinsi Bali adalah dengan melakukan layanan penjemputan gratis terhadap penderita gangguan jiwa yang di pasung (Kristianto, 2014).

Berbagai upaya yang dilakukan oleh pemerintah untuk meningkatkan pengetahuan dan kesadaran masyarakat terkait gangguan jiwa belum memberikan hasil yang signifikan. Sejumlah daerah di Indonesia masih mengaitkan gangguan jiwa dengan kepercayaan-kepercayaan yang berlaku di daerahnya masing-masing. Yogyakarta sebagai salah satu daerah yang kental dengan adat Jawa, memiliki beberapa kepercayaan terkait gangguan jiwa. Menurut hasil penelitian yang dilakukan oleh Subandi (2012) di Yogyakarta ditemukan bahwa, masyarakat Jawa pada umumnya memiliki kepercayaan bahwa gangguan jiwa disebabkan karena seseorang melakukan perbuatan yang melanggar ajaran Agama. Masyarakat Jawa percaya bahwa gangguan jiwa merupakan penyakit dapat disembuhkan karena diberikan oleh Tuhan sehingga memberikan dampak berupa harapan bagi masyarakat yang meningkatkan usaha masyarakat untuk berjuang dalam proses penyembuhan (Subandi, 2012).
Bali dikenal sebagai salah satu pulau yang sarat akan budaya dan memiliki kearifan lokal yang mengikat masyarakatnya. Kearifan lokal atau yang dikenal dengan istilah kearifan tradisional merupakan semua bentuk pengetahuan, keyakinan, pemahaman, dan wawasan serta adat kebiasaan atau etika yang menuntut perilaku manusia dalam kehidupan di dalam komunitas ekologis (Keraf dalam Yuniarto, 2013). Beberapa masyarakat Bali masih memandang gangguan jiwa sebagai akibat dari pengaruh roh jahat atau yang dikenal dengan istilah guna-guna dibandingkan dengan penyebab secara ilmiah. Pernyataan ini didukung oleh hasil penelitian Putro (2004) yang mengungkapkan bahwa sebagian besar masyarakat Bali memandang etiologi sakit gangguan jiwa sebagai jenis penyakit niskala atau non medis sehingga pilihan alternatif perawatan cenderung merujuk pada perawatan tradisional yakni datang ke paranormal atau yang biasa disebut dengan balian. Salah satu kasus penderita gangguan jiwa yang diyakini sebagai akibat dari pengaruh roh jahat atau guna-guna dialami oleh salah satu ODGJ pada berita yang ditulis oleh Suriyani (2016).

Selain pengobatan tradisional yang merujuk pada pengobatan melalui balian, sebagian kecil masyarakat Bali telah mengupayakan pengobatan gangguan jiwa melalui cara medis. Pernyataan peneliti ini didukung oleh hasil penelitian Putro (2004) yang menyatakan bahwa sebagian kecil masyarakat Bali langsung menempuh jalan medis tanpa melakukan perawatan rumah tangga dalam menangani gangguan jiwa, namun bagi yang belum berhasil sembuh, sebagian akan menempuh jalan medis kembali sedangkan sisanya memilih untuk mencari pengobatan melalui balian.

Berbagai keyakinan yang dimiliki oleh masyarakat Bali dalam memandang kondisi sehat dan sakit memengaruhi sikap masyarakat Bali dalam menyikapi permasalahan sehat dan sakit. Salah satu nilai atau kearifan lokal yang terkait dengan kondisi sehat dan sakit pada masyarakat Bali adalah konsep tri hita karana. Hasil penelitian yang dilakukan oleh Putro (2004) mengungkapkan bahwa kondisi sehat dan sakit masyarakat Bali dipengaruhi oleh konsep tri hita karana yang merupakan keseimbangan antara Sang Hyang Widhi (Tuhan Yang Maha Esa), bhuana agung (alam semesta), dan bhuana alit (manusia). Ketidakseimbangan yang terjadi antara ketiga hal tersebut menyebabkan individu berada dalam kondisi sakit. Gangguan jiwa merupakan salah satu kondisi sakit yang terjadi akibat adanya ketidakseimbangan antara Sang Hyang Widhi, bhuana agung dan bhuana alit. Terkait dengan gangguan jiwa, konsep tri hita karana mengarahkan manusia untuk hidup secara harmonis, saling mengerti kehidupan, dan merasakan dirinya tergantung dengan yang lainnya. Keharmonisan kehidupan membantu tubuh bekerja lebih ringan karena tubuh tidak berada dalam kondisi cemas dan depresi. Keharmonisan tersebut juga menyebabkan tubuh tidak mengeluarkan hormon yang menyebabkan stres berlebihan dan hormon kegembiraan akan dikeluarkan lebih banyak (Artana, 2014).

Selain tri hita karana, masyarakat Bali juga dekat dengan konsep karma phala. Karma phala memiliki arti yakni hasil dari suatu perbuatan (Suhardana, 2010). Karma phala menjadi 
sutau konsep yang penting bagi masyarakat Bali karena kharma phala bukan hanya hukum spiritual namun juga suatu prinsip yang menuntut tujuan baik dan perbuatan berdasarkan etika (Suhardana, 2010). Konsep karma phala mengajarkan individu untuk mengedalikan segala tindakan, pikiran dan emosi (Suhardana, 2010). Konsep karma phala yang melekat pada masyarakat Bali mengajarkan masyarakat Bali untuk berperilaku positif pada semua orang tak terkecuali ODGJ. Hal ini terkait dengan konsep dasar hukum dasar karma yang berkaitan erat dengan konsep karma phala. Hukum Karma merupakan hukum kausalitas atau hukum sebab akibat yang menegaskan bahwa setiap gerak atau karya pasti ada hasil perbuatannya (Astuti, Gurning, Purna, \& Rupa, 1998).

Berbagai nilai atau kearifan lokal yang melekat pada masyarakat Bali memberikan pengaruh positif yang mendorong masyarakat Bali untuk berperilaku saling menghargai, peduli, dan menjaga keharmonisan satu sama lain. Berbagai nilai atau kearifan lokal tersebut seharusnya mampu mengurangi stigma yang diterima oleh ODGJ di Bali karena nilai atau kearifan lokal tersebut secara langsung mengajarkan individu untuk berperilaku saling menghargai, peduli, dan menjaga keharmonisan satu sama lain, namun pada kenyataannya ODGJ di Bali masih mendapatkan stigma negatif dari lingkungan sekitar. Stigma negatif yang masih diterima oleh orang dengan gangguan jiwa di Bali dapat terjadi karena adanya perbedaan dalam penerapan nilai atau kearifan lokal pada masing-masing masyarakat Bali. Diperlukan adanya pemberian edukasi kepada masyarakat melalui sarana promosi kesehatan yang tepat guna mengurangi stigma terhadap ODGJ yang pada akhirnya berdampak positif pada proses penyembuhan ODGJ. Berdasarkan hal tersebut, peneliti tertarik untuk melakukan penelitian terkait penerapan nilai atau kearifan lokal dalam mengurangi stigma pada masyarakat Bali. Penelitian ini dilakukan dengan tujuan untuk megetahui pola penerapan nilai atau kearifan lokal pada masyarakat Bali yang dapat mengurangi stigma pada penderita gangguan jiwa di Bali. Penelitian ini juga diharapkan mampu memberikan edukasi kepada masyarakat, pemerintah dan keluarga ODGJ mengenai informasi yang tepat dalam mengurangi stigma terhadap ODGJ dan juga penanganan terhadap ODGJ. Berdasarkan pada permasalahan yang telah dipaparkan, peneliti merumuskan dua pertanyaan penelitian yaitu bagaimana stigma masyarakat Bali terhadap ODGJ dan bagaimana pengaruh konsep kearifan lokal masyarakat Bali dalam mengurangi stigma terhadap ODGJ.

\section{METODE PENELITIAN}

Penelitian ini menggunakan metode penelitian kualitatif yang dapat memberikan gambaran tentang suatu masalah, gejala, fakta, peristiwa dan realita secara luas dan mendalam sehingga diperoleh suatu pemahaman baru (Raco, 2010). Pendekatan yang digunakan pada penelitian ini yaitu menggunakan pendekatan fenomenologi yang berfokus pada menggali, memahami, dan menafsirkan arti fenomena, peristiwa dan hubungannya dengan orang-orang biasa dalam situasi tertentu (Yusuf, 2014). Pada penelitian ini, peneliti ingin menggali dan memahami fenomena penerapan kearifan lokal masyarakat Bali dan stigma masyarakat Bali terhadap ODGJ.
Kriteria responden pada penelitian ini dibagi menjadi dua yakni kriteria responden yang berperan sebagai tokoh agama dan juga kriteria responden sebagai masyarakat umum. Kriteria responden yang berperan sebagai tokoh agama adalah sebagai berikut laki-laki atau perempuan, bersuku Bali, lahir dan tumbuh besar di Bali, memiliki tetangga ODGJ, pernah berinteraksi dengan ODGJ, berperan sebagai tokoh agama dilingkungan masyarakat. Pemilihan responden dengan kategori tokoh agama didasari dengan alasan bahwa tokoh agama merupakan seseorang yang memiliki pemahaman yang lebih mengenai kearifan lokal dan juga tokoh agama merupakan salah satu tokoh yang dihormati di masyarakat sehingga diharapkan nantinya tokoh agama dapat menyampaikan informasi yang tepat mengenai topik gangguan jiwa dan kearifan lokal pada masyarakat sekitar tempat tinggalnya. Kriteria responden untuk masyarakat umum adalah sebagai berikut laki-laki atau perempuan, bersuku Bali dan bukan merupakan ahli pada bidang ilmu kejiwaan.

Responden yang digunakan pada penelitian ini sebanyak tujuh orang yang mana responden dengan kategori tokoh agama sebanyak 3 orang dengan inisial SA, YT dan GM dan responden dengan kategori masyarakat umum sebanyak 4 orang dengan inisial LS, AN, MW dan AR. Seluruh responden dalam penelitian ini telah memenuhi seluruh kriteria penelitian namun terdapat beberapa perbedaan karakteristik pada setiap responden. Perbedaan karakteristik pada setiap responden dibedakan dalam kriteria pendidikan terakhir dan juga status dan pekerjaan. Pada kriteria perbedaan latar belakang pendidikan terakhir, enam dari tujuh responden penelitian memiliki latar belakang pendidikan tingkat SMA. Satu orang responden memiliki latar belakang pendidikan S2. Perbedaan tingkat pendidikan pada masing-masing responden dapat menimbulkan perbedaan dalam memandang gangguan jiwa dan ODGJ sebagai bagian dari tema penelitian yang telah ditetapkan.

Karakteristik status dan pekerjaan pada responden penelitian ini terdapat tiga dari delapan responden bestatus sebagai tokoh agama dengan latar belakang pekerjaan sebagai dosen, wiraswasta dan pensiunan PNS. Seorang responden lain yang berstatus sebagai masyarakat umum bekerja sebagai pemantau jentik dan yang lainnya masih berstatus pelajar. Perbedaan latar belakang dan status masing-masing responden memungkinkan adanya perbedaan dalam menanggapi gangguan jiwa dan ODGJ sebagai bagian dari tema penelitian yang telah ditetapkan.

\section{Lokasi Pengumpulan Data}

Penelitian berlangsung di masing-masing tempat yang telah disepakati antara peneliti dan responden penelitian. Wawancara terhadap responden dengan inisial SA berlangsung di tempat kerja responden sedangkan wawancara terhadap responden YT dan GM dilaksanakan di tempat tinggal responden. Peneliti menggunakan 4 responden lain dengan inisial LS, AN, MW dan AR yang bersumber dari data yang diperoleh oleh kelas metode penelitian kualitatif Program Studi Psikologi Fakultas Kedokteran Universitas Udayana angkatan 2016. Wawancara terhadap responden LS, AN, dan MW dilaksanakan di rumah tempat tinggal responden 
sedangkan wawancara terhadap responden dengan inisial AR dilaksanakan di kampus responden. Observasi dilakukan pada masing-masing responden selama proses wawancara dilakukan.

\section{Teknik Pengambilan Data}

Teknik pengambilan data yang digunakan dalam penelitian ini adalah wawancara dan observasi. Wawancara merupakan percakapan tatap muka antara pewawancara dengan sumber informasi yang pada prosesnya pewawancara bertanya langsung kepada sumber informasi terkait suatu objek yang diteliti dan telah dirancang sebelumnya (Yusuf, 2014). Teknik wawancara yang digunakan dalam penelitian ini adalah teknik wawancara semi terstruktur karena dapat memudahkan peneliti dalam proses penggalian data dan juga dengan menggunakan teknik wawancara semi terstruktur memungkinkan peneliti untuk mendapatkan gambaran penerapan kearifan lokal Bali serta stigma masyarakat Bali terhadap ODGJ secara umum dengan menggunakan pertanyaan terbuka namun tetap dalam konteks yang dibutuhkan dalam penelitian. Peneliti memberikan informed consent sebagai tanda persetujuan responden untuk terlibat dalam penelitian ini sebelum dimulainya wawancara. Setelah mendapat persetujuan responden, peneliti merekam seluruh wawancara yang berlangsung dengan menggunakan telepon genggam.

Observasi merupakan proses mengamati subjek penelitian beserta lingkungannya dengan melakukan pencatatan dan perekaman atas perilaku yang diamati tanpa mengubah kondisi alamiah subjek dengan lingkungan sosialnya (Matthews \& Ross dalam Herdiansyah, 2015). Penelitian ini menggunakan jenis observasi partisipasi pasif. Menurut Sugiyono (2014) pada observasi pasrtisipasi pasif, peneliti berada di lokasi pengamatan namun tidak terlibat dalam kegiatan responden dan hanya berperan sebagai pengamat. Proses observasi dilakukan selama proses wawancara berlangsung yang dicatat dalam bentuk fieldnote. (Tabel 1. Waktu Pelaksanaan, Kode Data Rekaman, Verbatim dan Observasi. Terlampir)

\section{Teknik Analisis Data}

Teknik analisis data yang digunakan pada penelitian ini mengacu pada teknik coding dalam analisis data kualitatif menurut Strauss dan Corbin (2013). Mengacu pada tahapan proses koding menurut Strauss dan Corbin (2013) proses koding yang dilakukan pada penelitian ini terdiri dari tiga tahap yakni pengodean berbuka (open coding), pengodean berporos (axial coding) dan pengodean berpilih (selective coding). Pengodean berbuka (open coding) merupakan langkah awal analisis data dalam penelitian ini dan pengodean berbuka dilakukan dengan cara membaca data yang diperoleh dengan teliti kemudian memberikan kode atau label pada setiap data. Proses analisis data selanjutnya dilakukan dengan cara pengodean berporos (axial coding) yang dilakukan dengan cara mengelompokkan kode-kode yang memiliki makna serupa ke dalam satu kategori. Analisis data selanjutnya menggunakan pengodean berpilih (selective coding) yang dilakukan dengan cara memilih kategori inti yang berasal dari tahapan pengodean berporos (axial coding).

\section{Kredibilitas Penelitian}

Teknik yang digunakan untuk pemantapan kredibilitas penelitian dalam penelitian ini adalah teknik triangulasi. Triangulasi merupakan salah satu teknik uji kredibilitas data yang melihat sesuatu realitas dari berbagai sudut pandang atau perspektif sehingga data yang dihasilkan dapat lebih akurat (Suparno, 2008). Denzin (dalam Moleong 2014) membedakan empat macam triangulasi sebagai teknik pemeriksaan yang memanfaatkan penggunaan sumber, metode, penyidik, dan teori. Pada penelitian ini, peneliti melakukan triangulasi data dengan cara membandingkan data hasil observasi dengan data hasil wawancara, membandingkan keadaan dan perspektif responden dengan berbagai pendapat serta pandangan orang lain disekitarnya, membandingkan hasil wawancara dan observasi satu responden dengan responden lainnya serta membandingkan hasil wawancara responden dengan teori stigma dan kearifan lokal yang digunakan pada penelitian ini.

\section{Isu Etik}

Terdapat lima prinsip umum yang dikemukakan oleh APA (American Psychological Association) (dalam Herdiansyah, 2015) terkait kode etik profesional disiplin ilmu psikologi yaitu murah hati dan tidak mencelakai, ketaatan dan tanggung jawab, integritas, keadilan dan menghormati hak dan kehormatan orang lain. Berdasarkan prinsip yang telah dikemukakan oleh APA dan agar dapat menjaga penelitian dapat berlangsung dengan baik serta tidak membebani maupun merugikan para responden penelitian, maka peneliti melakukan langkah-langkah seperti memberikan persetujuan kepada responden yang berupa informed consent yang berisikan hak-hak dan kewajiban responden, menjelaskan kepada partisipan atau responden penelitian tentang hal yang terkait dengan penelitian yang akan dilakukan, termasuk semua kemungkinan resiko yang dapat terjadi terhadap responden penelitian, menjelaskan bahwa tidak adanya unsur dalam penelitian ini yang akan merugikan atau membahayakan responden, menjaga kerahasiaan data responden dengan tidak mencantumkan nama, lokasi/tempat maupun penyebutan nama selama proses penggalian data secara jelas, menyimpan hasil rekaman serta memberikan hasil penelitian kepada institusi dan responden jika diminta oleh responden atau institusi terkait.

\section{HASIL PENELITIAN}

Hasil penelitian ini terbagi kedalam 3 kategori utama yakni kearifan lokal masyarakat Bali, persepsi masyarakat terkait ODGJ dan perlakuan terhadap ODGJ. (Tabel 2. Kearifan Lokal Masyarakat Bali. Terlampir).

\section{Kearifan Lokal Masyarakat Bali}

\section{Makna Dasar Kearifan Lokal}

Hasil pengambilan data terhadap kedua kategori responden penelitian menunjukan bahwa masyarakat Bali dipengaruhi oleh konsep-konsep kearifan lokal seperti tat twam asi, tri pramana, tri kaya parisudha dan karma phala. Masyarakat Bali memandang tat twam asi sebagai sebuah konsep yang bermakna aku adalah kamu, kamu adalah aku. Konsep tat twam asi didasarkan pada prinsip rasa saling memiliki sehingga masyarakat Bali dapat merefleksikan apa yang 
dialami oleh orang lain sebagai bagian dari dirinya. Tri pramana merupakan konsep dasar mengenai potensi manusia lyang terdiri dari bayu, sabda dan idep. Bayu berarti tenaga, sabda berarti kemampuan bicara atau mengeluarkan suara dan idep yang berarti pikiran. Tri kaya parisudha merupakan konsep mengenai tiga perbuatan yang menjadi landasan etika Agama Hindu yang terdiri dari kayika parisudha, manacika parisudha dan wacika parisudha. Kayika parisudha berarti berbuat yang baik, manacika parisudha artinya berpikir yang baik dan wacika parisudha berarti bertutur kata yang baik. Karma phala memiliki arti buah dari perbuatan. Konsep karma phala mengajarkan bahwa setiap perbuatan akan mendapatkan hasil, baik perbuatan yang telah dilakukan maupun perbuatan yang akan dilakukan.

Peran Kearifan Lokal terhadap stigma pada ODGJ

Kearifan lokal pada masyarakat Bali dapat memiliki peranan dalam menurunkan stigma terhadap ODGJ. Selain dapat menurunkan stigma terhadap ODGJ, terdapat satu kearifan lokal masyarakat Bali yang dapat membentuk stigma terhadap ODGJ. Konsep karma phala sebagai salah satu kearifan lokal masyarakat Bali mampu menekan stigma terhada ODGJ. Merujuk pada konsep karma phala, masyarakat Bali umumnya merefleksikan apa konsekuensi yang akan diterima kepada dirinya jika masyarakat melakukan tindakan yang tidak baik kepada ODGJ sehingga masyarakat Bali cenderung akan berpikir kembali untuk mencemooh ataupun melakukan perilaku negatif terhadap ODGJ.

Selain dapat menurunkan stigma, konsep karma phala ternyata dapat membentuk tejadinya stigma masyarakat terhadap ODGJ. Makna konsep karma phala yang berarti buah dari hasil perbuatan dikaitkan oleh masyarakat sebagai salah satu penyebab terjadinya gangguan jiwa. Masyarakat menganggap bahwa penyebab gangguan jiwa adalah adanya kesalahan yang bersifat niskala (magis).

Kearifan lokal lain yang dapat menurunkan stigma terhadap ODGJ yakni tat twam asi. Konsep tat twam asi tat twam asi dapat berperan dalam mendorong hadirnya perilaku positif masyarakat Bali terhadap ODGJ. Merujuk pada konsep tat twam asi, masyarakat Bali umumnya merefleksikan apa yang terjadi pada ODGJ ke dalam dirinya sendiri sehingga masyarakat Bali yang cenderung akan berpikir kembali untuk memberikan label ataupun perilaku buruk terhadap ODGJ.

Selain tat twam asi, konsep tri pramana sebagai salah satu kearifan lokal masyarakat Bali juga mampu berperan dalam menekan stigma ODGJ. Sesuai dengan konsep dasar tri pramana, masyarakat Bali memiliki kepercayaan bahwa setiap manusia termasuk ODGJ memiliki potensi yang sama dalam menjalani kehidupan karena setiap manusia lahir dengan memiliki bayu, sabda dan idep. Hal ini berpengaruh pada pemahaman masyarakat bahwa setiap manusia adalah sama dan setiap manusia berasal dari Tuhan. Pemahaman masyarakat yang sejalan dengan konsep tri pramana mendorong masyarakat untuk memberikan perhatian dan penghormatan bagi ODGJ.

Konsep tri kaya parisudha sebagai salah satu kearifan lokal masyarakat Bali juga mampu menekan stigma terhadap
ODGJ. Sesuai dengan dasar konsep tri kaya parisudha yaitu sebagai landasan etika perbuatan dalam agama Hindu, masyarakat Bali diajarkan agar selalu berpikir, berbicara dan berperilaku yang baik. Masyarakat yang memahami konsep tri kaya parisudha mendorong masyarakat untuk berpikir, berbicara dan berperilaku yang baik kepada semua orang termasuk juga dengan ODGJ.

Bentuk Penerapan Kearifan Lokal Masyarakat Bali

(Tabel 3. Bentuk Penerapan Kearifan Lokal. Terlampir). Keempat konsep kearifan lokal masyarakat Bali yang dipercayai oleh responden penelitian dapat mengurangi stigma terhadap ODGJ memiliki perbedaan dalam bentuk penerapannya. Konsep tat twam asi sebagai sebuah konsep yang bermakna aku adalah kamu, kamu adalah aku didasarkan pada prinsip rasa saling memiliki sehingga masyarakat Bali dapat merefleksikan apa yang dialami oleh orang lain sebagai bagian dari dirinya. Berdasarkan hal tersebut konsep tat twam asi dapat digambarkan sebagai rasa empati. Bentuk penerapan konsep tat twam asi yang dilakukan oleh masyarakat Bali tercermin dalam sikap masyarakat yang tidak mencemooh ODGJ karena masyarakat Bali merefleksikan hal tersebut ke dalam dirinya sendiri. Responden memiliki pikiran seperti bagaimana kalau responden yang sakit seperti itu, bagaimana kalau saudara responden yang seperti itu, seperti apa kelakuan responden saat responden sakit seperti itu, dan apa yang bisa responden lakukan untuk keluarganya kalau keluarga responden mengalami sakit seperti itu. Pikiran-pikiran seperti inilah yang kemudian menjadikan landasan masyarakat Bali untuk tidak memberikan stigma terhadap ODGJ. Pikiranpikiran tersebut juga mendorong masyarakat Bali untuk lebih memberikan rasa kasih sayang dan perawatan kepada ODGJ. Masyarakat Bali percaya bahwa masyarakat Bali yang menerapkan konsep tat twam asi tidak akan memberikan cemoohan maupun stigma kepada ODGJ ketika masyarakat Bali mampu merefleksikan dan merasakan rasa sakit yang dirasakan oleh ODGJ jika dicemooh maupun diberikan stigma.

Konsep Karma phala memiliki arti buah dari perbuatan dan pada konsep karma phala mengajarkan kepada masyarakat Bali bahwa setiap perbuatan akan mendapatkan hasil, baik perbuatan yang telah dilakukan maupun perbuatan yang akan dilakukan. Berdasarkan hal tersebut masyarakat Bali akan mengontrol segala tindakan yang akan dilakukan baik perbuatan yang baik maupun perbuatan yang buruk. Berdasarkan data penelitian, bentuk penerapan konsep karma phala oleh masyarakat Bali tercermin dalam perilaku tidak mencemooh ODGJ karena masyarakat Bali memercayai bahwa apabila masyarakat Bali mencemooh ODGJ maka di suatu hari nanti ia akan mendapatkan cemoohan maupun kepercayaan seperti akan terkena gangguan jiwa di suatu hari nanti apabila memberikan cemoohan kepada ODGJ. Pikiranpikiran seperti inilah yang kemudian menjadikan landasan masyarakat Bali untuk tidak memberikan stigma terhadap ODGJ.

Konsep tri pramana yang tertanam pada masyarakat Bali dapat diartikan sebagai setiap manusia termasuk ODGJ memiliki potensi yang sama dalam menjalani kehidupan karena setiap manusia lahir dengan memiliki bayu, sabda dan 
idep yang kemudian pengertian ini memengaruhi pemahaman masyarakat bahwa setiap manusia adalah sama dan setiap manusia berasal dari Tuhan. Pemahaman masyarakat yang sejalan dengan konsep tri pramana akan mendorong masyarakat untuk memberikan perhatian dan penghormatan bagi setiap manusia termasuk ODGJ. Adapun bentuk penerapan konsep tri pramana tercermin dalam tindakan salah satu responden yang melarang temannya memberikan perkataan buruk terhadap ODGJ karena responden menganggap bahwa ODGJ juga manusia. Berdasarkan hal tersebut responden memiliki pikiran bahwa mungkin ODGJ mengalami gangguan jiwa karena memiliki masalah dan kemudian stres dan seharusnya diberikan pertolongan seperti dirangkul untuk berobat dan mengajak ODGJ berbicara seperti orang normal pada umumnya bukan dihakimi dan diberikan perkataan yang tidak baik.

Konsep tri kaya parisudha merupakan konsep mengenai tiga perbuatan yang menjadi landasan etika Agama Hindu yang terdiri dari kayika parisudha, manacika parisudha dan wacika parisudha yang mana kayika parisudha berarti berbuat yang baik, manacika parisudha artinya berpikir yang baik dan wacika parisudha berarti bertutur kata yang baik. Sebagai landasan etika perbuatan dalam agama Hindu, Konsep tri kaya parisudha mendorong masyarakat untuk berpikir, berbicara dan berperilaku yang baik kepada semua orang termasuk juga dengan ODGJ.

Adapun bentuk penerapan konsep tri hita karana terbagi kedalam tiga komponennya dan tercermin sebagai berikut, pertama berpikir yang baik tercermin dari tindakan memandang orang lain sebagai bagian dari kehidupan masyarakat dan selalu berpikiran positif terhadap suatu hal misalnya ketika ODGJ datang mendekat, dengan berpikir yang baik masyarakat akan menganggap bahwa ODGJ itu orang yang sedang sakit sehingga tidak perlu takut dan mengusir. Berkata yang baik dapat tercermin dari perilaku menyapa ODGJ, mengajak ODGJ berkomunikasi secara normal bukan mencela maupun mencemooh ODGJ. Berperilaku yang baik tercermin dalam perilaku merangkul ODGJ, memberikan perawatan, memberikan kasih sayang, dan memberikan bantuan instrumental bukan berupa perilaku kekerasan dan juga diskriminasi.

\section{Penerapan kearifan lokal masyarakat Bali}

Berdasarkan data penelitian, responden dengan kategori tokoh agama menilai bahwa penerapan konsep-konsep kearifan lokal pada masyarakat Bali masih belum sempurna. Hal ini terjadi karena penerapan kearifan lokal tersebut hanya terbatas pada seseorang yang telah dikenal, diketahui atau dekat dengan masyarakat. Masyarakat cenderung memiliki kesulitan untuk menerapkan konsep-konsep kearifan lokal tersebut pada seseorang yang baru dikenal atau orang yang dianggap asing.

\section{Persepsi Masyarakat Terkait ODGJ}

(Tabel 4. Persepsi Masyarakat Terkait ODGJ. Terlampir). Secara umum, hasil penggalian data menunjukkan bahwa terdapat persamaan antar dua kategori responden pada persepsi mengenai ciri fisik ODGJ. Persamaan ciri fisik ODGJ yang diungkapan oleh kedua kategori responden penelitian diklasifikasikan berdasarkan cara berpikir, berprilaku, dan berbicara. Secara umum, responden penelitian menilai bahwa ODGJ berperilaku, berpikir dan berbicara dengan cara yang tidak normal atau berbeda dengan masyarakat pada umumnya. Terdapat ciri fisik lainnya yang diungkapkan oleh responden dengan kategori masyarakat umum. Masyarakat umum memandang bahwa ODGJ ialah individu yang berpenampilan kumal, tidak terawat dan berpenampilan berbeda dari orang normal pada umumnya.

Berdasarkan hasil penggalian data, diperoleh fakta bahwa terdapat persamaan antar kedua kategori responden penelitian pada persepsi mengenai penyebab gangguan jiwa. Secara umum, responden penelitian pada kategori tokoh agama dan masyarakat umum memercayai bahwa terdapat dua faktor utama yang menjadi penyebab gangguan jiwa yakni faktor medis dan non medis. Secara medis, gangguan jiwa disebabkan oleh adanya permasalahan ekonomi, stres, pendidikan, asmara, dan depresi, sedangkan secara non medis gangguan jiwa diakibatkan oleh adanya kesalahan atau kekurangan spiritual, dan gangguan secara niskala.

Hasil penelitian menunjukkan bahwa secara umum responden penelitian mengistilahkan atau memberikan label kepada ODGJ sebagai orang gila, sakit, sakit jiwa, dan orang yang 'hang'. Berdasarkan hasil penggalian data, diperoleh fakta bahwa terdapat perbedaan diantara kedua kategori responden pada persepsi mengenai stereotip ODGJ. Responden penelitian yang berasal dari kategori masyarakat umum menganggap bahwa ODGJ umumnya terlihat di jalan dengan penampilan yang kumal, tidak terawat, berpenampilan berbeda dari orang normal pada umumnya dan mengganggu keamanan. Responden penelitian yang berasal dari kategori masyarakat umum juga menganggap bahwa ODGJ mengalami kehilangan kesadaran tentang dirinya yang merujuk pada ketidakmampuan dalam mengingat identitas dirinya sendiri maupun segala aktivitas yang dilakukan. Masyarakat umum juga menganggap bahwa gangguan jiwa merupakan gangguan yang tidak dapat disembuhkan.

\section{Perlakuan Terhadap ODGJ}

(Tabel 5. Perlakuan Terhadap ODGJ. Terlampir). Secara umum, hasil penelitian menunjukan bahwa terdapat dua kategori perlakuan yang ditunjukan masyarakat terhadap ODGJ yakni sikap positif dan negatif. Sikap positif yang ditunjukan masyarakat terdapat ODGJ tercermin pada perilaku merangkul ODGJ, mencari tahu faktor penyebab gangguan jiwa pada ODGJ, memberi bantuan instrumental, memberi saran pengobatan, menghadirkan rasa aman dan percaya pada diri ODGJ, memberi kesejukan, mempercayakan tanggung jawab pekerjaan pada ODGJ, menunjukan rasa prihatin, menghargai ODGJ, memberi kedamaian, memberi perhatian dan kasih sayang, memperlakukan ODGJ sesuai etika, dan memberi pengobatan terhadap ODGJ. Di sisi lain, sikap negatif yang ditunjukkan masyarakat terhadap ODGJ adalah sikap tidak ingin melibatkan diri terlalu jauh, cuek, tidak berani mendekat dan diskriminasi. Sikap negatif berupa diskriminasi terhadap ODGJ terjadi karena adanya pandangan masyarakat bahwa ODGJ bukan manusia yang suci sehingga dalam proses bermasyarakat, ODGJ kerap dijauhkan. 


\section{PEMBAHASAN DAN KESIMPULAN}

\section{Pembahasan}

Peneliti akan membahas beberapa topik terkait dengan hasil penelitian yang ditemukan oleh peneliti. Topik yang akan dibahas antara lain, konsep kearifan lokal yang dapat membentuk stigma, sosialisasi kepada masyarakat dan stigma reduction.

\section{Konsep Kearifan Lokal yang Dapat Membentuk Stigma}

Berdasarkan hasil penelitian ini, kearifan lokal mampu untuk menurunkan stigma masyarakat terhadap ODGJ, namun terdapat juga kearifan lokal yang dapat membentuk stigma terhadap ODGJ. Menurut Sutardi (2007) jika dilihat secara mendalam, tidak selamanya kearifan lokal mengandung nilai kerukunan namun terdapat hal-hal yang dapat menyebabkan perpecahan, benturan pemahaman dan makna. Benturan pemahaman dan makna dalam memaknai kearifan lokal inilah yang dapat membentuk stigma terhadap ODGJ.

Konsep karma phala sebagai salah satu kearifan lokal masyarakat Bali yang mampu mengurangi stigma terhadap ODGJ ternyata juga dapat membentuk stigma terhadap ODGJ. Menurut Suhardana (2010) karma phala dapat diartikan sebagai buah atau hasil perbuatan yang apabila melakukan perbuatan baik maka hasilnya pun baik dan bila melakukan perbuatan jahat maka hasilnya pun buruk. Merujuk pada konsep karma phala, masyarakat Bali umumnya merefleksikan apa konsekuensi yang akan diterima kepada dirinya jika masyarakat melakukan tindakan yang tidak baik kepada ODGJ sehingga masyarakat Bali cenderung akan berpikir kembali untuk melakukan perilaku negatif terhadap ODGJ. Hal inilah yang menjadikan karma phala sebagai kearifan lokal yang dapat mengurangi stigma terhadap ODGJ.

Sejalan dengan definisi dari karma phala, masyarakat Bali memiliki pandangan bahwa salah satu penyebab gangguan jiwa adalah adanya kesalahan individu secara niskala yang dilakukan individu pada masa hidupnya yang akhirnya menyebabkan individu tersebut mengalami gangguan jiwa. Pandangan masyarakat Bali terhadap penyebab gangguan jiwa ini tidak sesuai dengan pernyataan mengenai penyebab gangguan jiwa yang diungkapkan oleh Darmabrata dan Nurhidayat (2003). Darmabrata dan Nurhidayat (2003) mengungkapkan bahwa faktor penyebab gangguan jiwa diantaranya organobiologik yaitu gangguan jiwa yang disebabkan oleh kelainan pada otak yang ditinjau dari aspek biokimiawi, faali maupun anatomi, faktor psikoedukatif yaitu gangguan jiwa yang disebabkan oleh gangguan hambatan perkembangan kepribadian, faktor sosiokultural yaitu gangguan jiwa yang disebabkan oleh akibat kegagalan dalam mengatasi konflik yang terjadi di dalam masyarakat. Pandangan masyarakat yang tidak sesuai inilah yang menyebabkan munculnya stigma negatif masyarakat terhadap ODGJ.

Adanya stigma yang melekat pada ODGJ memberikan beberapa dampak pada diri ODGJ. Wahl (dalam Boyd, 2005) mengungkapkan bahwa stigma yang diberikan pada ODGJ membuat ODGJ merasa kecil hati, terluka, marah dan memiliki harga diri yang rendah. Mengacu pada pernyataan yang diungkapkan oleh Wahl (dalam Boyd, 2005) ceramah yang dilakukan oleh praktisi kesehatan dan tokoh agama diharapkan dapat memberikan hasil berupa berkurangnya stigma masyarakat terhadap ODGJ dan juga dengan berkurangnya stigma masyarakat terhadap ODGJ maka masyarakat dapat melakukan perilaku yang positif berupa memberikan dukungan sosial kepada ODGJ agar ODGJ merasa berdaya yang akhirnya dapat memberikan kesembuhan bagi ODGJ.

Stigma dan diskriminasi yang diberikan kepada ODGJ ditemukan juga sebagai sebuah penghalang yang signifikan dalam perilaku mencari bantuan pada ODGJ (Corrigan, dalam Lane \& Tribe, 2017). Adanya stigma masyarakat yang menganggap bahwa gangguan jiwa disebabkan karena hal yang bersifat niskala juga menjadikan masyarakat Bali pada umumnya masih mendahulukan melakukan pengobatan tradisional dibandingkan mencari bantuan tenaga ahli. Stigma masyarakat terhadap ODGJ perlu dikurangi untuk mengurangi dampak-dampak yang terjadi akibat adanya stigma yang diberikan kepada ODGJ.

Sosialisasi Kepada Masyarakat

Masih adanya pandangan masyarakat yang tidak sesuai terhadap ODGJ, maka diperlukan suatu solusi untuk menangani masalah tersebut. Praktisi kesehatan terutama yang memiliki keahlian pada bidang gangguan jiwa memiliki peran penting untuk memberikan informasi yang benar terkait dengan fakta-fakta mengenai gangguan jiwa kepada masyarakat. Metode ceramah dapat digunakan oleh praktisi kesehatan sebagai media pembelajaran kepada masyarakat. Metode ceramah digunakan karena metode ceramah merupakan metode yang paling ekonomis untuk menyampaikan informasi dan paling efektif dalam mengatasi kelangkaan literatur yang sesuai dengan jangkauan daya beli serta daya paham peserta ceramah (Simamora, 2009).

Praktisi kesehatan dapat bekerjasama dengan tokoh agama dalam melakukan sosialisasi kepada masyarakat terkait dengan memberikan informasi yang benar mengenai gangguan jiwa yang dipadukan dengan nilai-nilai agama dan kehidupan masyarakat Bali. Jalinan kerja sama diantara praktisi kesehatan dengan tokoh agama sebagai salah satu tokoh yang dihormati oleh masyarakat dilakukan dengan tujuan agar menjadikan masyarakat untuk lebih memahami dan menjalankan informasi-informasi yang diberikan. Raven dan French (dalam Taylor, Peplau \& Sears, 2009) mengklasifikasikan bagaimana cara orang memengaruhi satu sama lain. Salah satu klasifikasi yang diungkapkan oleh Raven dan French (dalam Taylor, Peplau \& Sears, 2009) adalah orang terpengaruh karena keahlian yang diartikan sebagai orang akan tunduk pada ahli dan mengikuti nasihatnya karena percaya bahwa pengetahuan yang dimiliki oleh ahli akan membantu dalam mencapai tujuan.

Kerja sama antara praktisi kesehatan dan tokoh agama juga memiliki manfaat yaitu adanya pertukaran informasi diantara kedua belah pihak. Pertukaran informasi yang terjadi yaitu praktisi kesehatan dapat memahami isu-isu kesehatan jiwa yang dikombinasikan dengan kearifan lokal masyarakat Bali dan begitu juga dengan tokoh agama yang dapat memahami 
isu kesehatan jiwa lebih mendalam. Sejalan dengan manfaat tersebut, adanya nilai-nilai kearifan lokal yang dipadukan dengan ilmu-ilmu pengetahuan terkait gangguan jiwa saat ceramah diberikan dapat memiliki dampak yang positif. Penelitian yang dilakukan oleh Demaio (2011) menemukan bahwa dengan menggunakan kearifan lokal yang tepat dalam promosi kesehatan dapat meningkatkan keberhasilan memahami suatu hal dan meningkatkan jangka waktu perubahan perilaku yang positif. Adanya ceramah sebagai media sosialisasi kepada masyarakat yang dilakukan oleh praktisi kesehatan bersama dengan tokoh agama diharapkan mampu memberikan dampak positif berupa berkurangnya stigma masyarakat terhadap ODGJ.

Selain menggunakan metode ceramah, metode lain yang dapat digunakan untuk memberikan sosialisasi kepada masyarakat adalah dengan cara memberikan materi maupun kurikulum terkait dengan kesehetan mental pada proses pendidikan formal. Menurut Corrigan dan Penn (dalam Gaebel, Rossler, \& Sartorius, 2017) program edukasi merupakan salah satu cara untuk mengubah stigma publik dengan memberikan faktafakta dan menghapus stereotip negatif dan mitos terkait gangguan jiwa yang ada di masyarakat. Pernyataan Corrigan juga didukung oleh hasil penelitian yang dilakukan oleh Mas dan Hatim (2002) yang menemukan bahwa individu dengan tingkat pengetahuan terkait gangguan jiwa yang lebih tinggi cenderung lebih sedikit memberikan stigma kepada ODGJ dibandingkan dengan individu dengan tingkat pengetahuan terkait gangguan jiwa yang rendah. Pemberian kurikulum terkait kesehatan mental pada tingkat sekolah bertujuan agar masyarakat memiliki pengetahuan terkait dengan kesehatan mental sejak dini yang pada akhirnya akan memberikan dampak tidak adanya lagi stigma terhadap ODGJ.

Metode lain yang dapat digunakan sebagai sosialisasi adalah dengan menggunakan pendekatan budaya. Pementasan wayang yang berisikan materi kesehatan mental dan nilai kearifan lokal dipilih sebagai salah satu metode sosialisasi dengan menggunakan pendekatan budaya karena wayang mampu menyajikan kata-kata mutiara yang bukan saja untuk persembahyangan, meditasi, pendidikan, pengetahuan dan hiburan tetapi juga menyediakan fantasi untuk nyanyian, lukisan estetis dan menyajikan imajinasi puitis untuk petuahpetuah religius yang mampu mempesona dan menggetarkan jiwa manusia yang mendengarnya (Mulyono dalam Purwadi, 2006). Keefektifan pementasan wayang untuk memberikan informasi kepada masyarakat yang diharapkan mampu mengurangi stigma terhadap ODGJ belum dapat dibuktikan namun jika dikemas dan disajikan dengan benar maka pementasan wayang dapat secara efektif meningkatkan hasil belajar ketika digunakan sebagai media pembelajaran. Hasil penelitian yang dilakukan oleh Septa dan Khoiri (2010) menunjukkan bahwa penggunaan wayang sebagai media pembelajaran fisika dapat meningkatkan hasil belajar siswa yang terlihat dengan adanya peningkatan rata-rata hasil belajar mata pelajaran ilmu pengetahuan alam fisika pada ranah kognitif maupun afektif siswa. Berdasarkan potensi-potensi yang telah disebutkan diatas diharapkan dengan menggunakan pementasan wayang sebagai sarana sosialisasi dalam menyampaikan informasi mengenai kesehatan mental dan juga kearifan lokal diharapkan mampu memudahkan masyarakat untuk memahami dan kemudian menerapkan informasi yang sudah diberikan sehingga pada akhirnya stigma pada ODGJ akan menurun.

Stigma Reduction

Berkurangnya stigma masyarakat terhadap ODGJ merupakan tujuan yang ingin dicapai dalam penelitian ini. Berkurangnya stigma terhadap ODGJ akan memberikan berbagai dampak bagi ODGJ, keluarga ODGJ, pemerintah dan juga masyarakat. Menurut hasil penelitian yang dilakukan oleh Rusch, EvansLacko, Henderson, Flach dan Thornicroft (2011) ditemukan bahwa meningkatkan pengetahuan dan sikap positif tentang gangguan jiwa di kalangan masyarakat umum dapat meningkatkan sejauh mana individu mencari pertolongan dengan menggunakan layanan kesehatan dan mengurangi kerahasiaan yang pada akhirnya, dampak stigma gangguan jiwa dapat dikurangi dan situasi individu dengan gangguan jiwa membaik. Mengacu pada hasil penelitian yang dilakukan oleh Rusch, dkk. (2011) dampak bagi ODGJ ketika stigma terhadap ODGJ berkurang adalah penggunaan layanan kesehatan meningkat yang akan memberikan kesembuhan bagi diri ODGJ.

Berkurangnya stigma juga akan memberikan dampak bagi keluarga yang memiliki anggota keluarga yang mengalami gangguan jiwa. Menurut U.S. Department of Health and Human Service (dalam Boyd, 2005) dampak yang terjadi akibat adanya stigma terhadap anggota keluarga ODGJ antara lain berdampak pada menurunnya harga diri dan mengalami kesulitan dalam mencari teman dan juga pekerjaan. Hasil penelitian yang dilakukan oleh Yusuf, Tristiana, Nihayati, Fitryasari dan Hilfida (2016) menemukan bahwa sampai saat ini stigma masyarakat tentang gangguan jiwa masih dirasakan oleh keluarga, menyebabkan beban keluarga, keluarga merasakan keretakan hubungan keluarga, gangguan aktivitas keluarga, penurunan status kesehatan dan hubungan sosial terbatas. Berkurangnya stigma kepada keluarga akan berdampak positif bagi keadaan psikologis keluarga yang memiliki anggota keluarga ODGJ. Beban-beban psikologis yang telah hilang akan berpengaruh positif dalam memperbaiki kembali hubungan sosial di dalam keluarga maupun dilingkungan masyarakat.

Berkurangnya stigma terhadap ODGJ akan memberikan dampak yang positif pada masyarakat. Hasil penelitian ini menunjukkan bahwa masyarakat cenderung takut berinteraksi dengan ODGJ karena masyarakat merasa ODGJ berbahaya dan suatu saat dapat mengamuk. Perasaan takut masyarakat terjadi akibat kurangnya pengetahuan masyarakat terkait kesehatan mental yang kemudian muncul stereotip bahwa ODGJ merupakan orang yang berbahaya. Kekhawatiran masyarakat karena masih adanya stigma dan kurangnya pengetahuan terkait kesehatan jiwa tersebut akan hilang setelah stigma masyarakat terhadap ODGJ berkurang.

Penggunaan layanan kesehatan yang rendah akibat adanya stigma masyarakat terhadap ODGJ akan berubah ketika stigma terhadap ODGJ menurun. ODGJ akan menggunakan fasilitas layanan kesehatan ketika stigma terhadap dirinya menghilang. Berkaca pada hal ini, pemerintah sebaiknya mempersiapkan 
fasilitas kesehatan dengan lebih baik dan juga memperbaiki masalah-masalah yang terdapat dalam program jaminan kesehatannya. Menurut artikel yang ditulis oleh Ari (2017) ODS di Bali masih mengalami kesulitan dalam mengakses JKN seperti permintaan mengurus usulan JKN yang ditolak dan sedikitnya stok obat bagi ODS. Program jaminan kesehatan yang telah dibuat oleh pemerintah memang sudah memberikan jaminan bagi berbagai tipe gangguan jiwa namun kendala-kendala yang terjadi dapat mengakibatkan penderita gangguan jiwa kesulitan untuk berobat yang berdampak bagi kesembuhan penderita gangguan jiwa tersebut.

\section{Kesimpulan dan Saran}

\section{Kesimpulan}

Dapat disimpulkan bahwa terdapat Berbagai pandangan masyarakat Bali muncul terkait dengan ODGJ. Pandanganpandangan masyarakat yang muncul memengaruhi perlakuan dan persepsi masyarakat terhadap ODGJ. Perlakuan dan persepsi masyarakat yang muncul dapat bersifat positif dan juga negatif. Masyarakat Bali memiliki berbagai macam kearifan lokal. Terdapat empat macam kearifan lokal masyarakat Bali yang dapat menurunkan stigma masyarakat terhadap ODGJ yakni karma phala, tat twam asi, tri kaya parisudha dan tri pramana. Kearifan lokal masyarakat Bali selain dapat menurunkan stigma terhadap ODGJ juga dapat berperan dalam membentuk stigma terhadap ODGJ. Konsep karma phala merupakan salah satu kearifan lokal masyarakat Bali yang dapat membentuk stigma terhadap ODGJ. Sosialisasi mengenai topik kesehatan jiwa dan kearifan lokal diperlukan agar masyarakat dapat menerima fakta yang benar terkait isu gangguan jiwa sehingga stigma yang sebelumnya ada bisa menjadi berkurang. Sosialisasi dapat dilakukan dengan 3 cara yaitu dengan menggunakan ceramah yang dilakukan oleh tenaga kesehatan bersama dengan tokoh agama, memberikan materi atau kurikulum terkait dengan kesehetan mental pada proses pendidikan formal, serta dengan menggunakan pendekatan budaya yang dilakukan dengan cara melakukan pementasan wayang dengan topik kesehatan jiwa dan kearifan lokal.

\section{$\underline{\text { Saran }}$}

Penelitian ini tentu saja memiliki keterbatasan, yaitu Penelitian ini hanya berfokus pada stigma masyarakat Bali dengan kategori responden tokoh agama dan masyarakat umum serta hanya mengetahui kearifan lokal apa saja yang dapat berpengaruh terhadap stigma masyarakat karena hanya menggunakan metodelogi penelitian kualitatif. Berdasarkan keterbatasan tersebut, peneliti selanjutnya diharapkan mampu mengkaji lebih dalam terkait dengan seberapa besar pengaruh kearifan lokal dalam mengurangi maupun membentuk stigma masyarakat terhadap ODGJ dan menggunakan responden dengan kategori yang lebih luas sehingga hasil penelitian yang diperoleh akan menjadi lebih kaya akan informasi.

\section{DAFTAR PUSTAKA}

Adilamarta, N. (2011). Hubungan tingkat pengetahuan dan sikap masyarakat dengan penerimaan masyarakat terhadap individu yang menderita gangguan jiwa di kelurahan Surau Gadang wilayah kerja Puskesmas Nanggalo Padang. Diunduh dari: http://repo.unand.ac.id/267/ 6 September 2016.
Anderson, R., Waskita, D. (2015 Agustus). Cara UGM atasi masalah gangguan jiwa di Yogyakarta. Diakses dari: http:/www.viva.co.id/kemenpar/read/660259-cara-ugmatasi-masalah-gangguan-jiwa-di-yogyakarta 1 Juli 2017.

Anna, L. K. (2012 Maret). Penyebab kambuhnya pasien gangguan jiwa. Diakses dari: http://lifestyle.kompas.com/read/2012/03/20/15433782/Pen yebab.Kambuhnya $\% 20 \% 20 \% 20$.Pasien.Gangguan.Jiwa 6 September 2016.

Ari, H. (2017 Februari). Susahnya mengakses JKN untuk ODS di Bali. Diakses dari: https://balebengong.net/kabaranyar/2017/02/21/jkn-untuk-ods.html, 20 Mei 2017.

Artana, I W. (2014). Tri hita karana meningkatkan kualitas modal manusia dari persfektif kesehatan. Piramida: Jurnal Kependudukan dan Pengembangan Sumber Daya Manusia, 10(2), 100-105.

Astuti, R., Gurning, E. T., Purna, I. M., \& Rupa, I. W. (1998). Kajian nilai budaya naskah kuno kakawin aji palayon kakawin aji palayon. Jakarta: Direktorat Jenderal Kebudayaan.

Balitbang Kemenkes RI. (2013). Riset kesehatan dasar; RISKESDAS. Jakarta: Balitbang Kemenkes RI.

Banjarnahor, D. (2014 Juli). RSJ Bali andalkan Puskesmas untuk laporkan pasien gangguan kejiwaan. Diakses dari: http://bali.bisnis.com/read/20140730/1/46258/rsj-baliandalkan-puskesmas-untuk-laporkan-pasien-gangguankejiwaan 1 Juli 2017.

Boyd, M. A. (2005). Psychiatric nursing: Contemporary practice. Philadelphia: Lippincott Williams \& Wilkins.

Darmabrata, W. \& Nurhidayat, A.W. (2003). Psikiatri forensik. Jakarta: EGC.

Demaio, A. (2011). Local wisdom and health promotion: Barrier or catalyst. Asia Pacific Journal of Public Health, 23(2), 127132. Doi: $10.1177 / 1010539509339607$.

Eppang, L. (2016 Desember). Bencana tsunami, salah satu penyebab gangguan jiwa di Aceh. Diakses dari: http://www.netralnews.com/news/kesehatan/read/40128/be ncana.tsunami..salah.satu.penyebab.gangguan.jiwa.di.aceh 1 Juli 2017.

Gaebel, W., Rossler, W., \& Sartorius, N. (2017). The stigma of mental illness - End of the story. Cham: Springer.

Herdaetha, A. (2015 Oktober). Memartabatkan orang dengan gangguan jiwa. Diakses dari: http://www.solopos.com/2015/10/11/gagasanmemartabatkan-orang-dengan-gangguan-jiwa-650652 20 September 2016.

Herdiyansyah, H. (2015). Metodologi penelitian kualitatif untuk ilmu psikologi. Jakarta: Salemba Humanika.

Ide, P. (2010). Whole brain training for social intelligent. Jakarta: PT Elex Media Komputindo.

Kementerian Kesehatan. (2014). Undang-undang no 18 tahun 2014 tentang kesehatan jiwa. Diunduh dari: http://binfar.kemkes.go.id/?wpdact=process\&did=MjAxlm hvdGxpbms, 30 Juli 2016.

Kristianto, F. (2014 Agustus). Rumah sakit jiwa Bangli jemput orang gila. Diakses dari: http://bali.bisnis.com/read/20140821/1/46477/rumah-sjbangli-jemput-orang-gila 5 Oktober 2016.

Kusuma, W. (2016 Juli). Jumlah penderita skizofrenia di Yogyakarta tertinggi kedua nasional. Diakses dari: http://nationalgeographic.co.id/berita/2016/07/jumlahpenderita-skizofrenia-di-yogyakarta-tertinggi-keduanasional 2 Juli 2017.

Lane, P. \& Tribe, R. (2017). Anti-discriminatory practice in mental health for older people. London: Jessica Kingsley Publishers. 
Mas, A., \& Hatim, A. (2002). Stigma in mental illness: Attitudes of medical students towards mental illness. The Medical Journal of Malaysia, 57(4), 433-444.

Moleong, J. L. (2014). Metode penelitian kualitatif. Bandung: PT Remaja Rosdakarya.

Muhammad, D. (2015 Februari). Bali sinergikan JKBM ke JKN $2017 . \quad$ Diakses dari: http://nasional.republika.co.id/berita/nasional/daerah/15/02/ 10/njjn1j-bali-sinergikan-jkbm-ke-jkn-2017 25 Maret 2017.

Munir, S. (2016 Februari). Kemensos targetkan Indonesia bebas pasung pada 2017. Diakses dari: https://nasional.sindonews.com/read/1089039/15/kemensos -targetkan-indonesia-bebas-pasung-pada-2017-1456692720 30 September 2016

Nurdin, I. (2016 Oktober). Penderita gangguan jiwa di Aceh masih tinggi. Diakses dari: http://portalsatu.com/read/health/penderita-gangguan-jiwadi-aceh-masih-tinggi-194412 Juli 2017.

Parama, I. D. M. S. (2015 Februari). Mengejutkan, 9.000 orang di Bali dinyatakan gila. Diakses dari: http://bali.tribunnews.com/2015/12/29/mengejutkan-9000orang-di-bali-dinyatakan-gila?page=all 31 Juli 2016.

Purwadi. (2006). Nilai pendidikan budi pekerti dalam seni pewayangan. Kejawen, 1(2), 62-78.

Putro, B. D. (2004). Gangguan jiwa (Buduh) di Bali sebagai fenomena budaya: Studi persepsi dan perilaku pilihan perawatan gangguan jiwa orang Bali. Diakses dari: http://etd.repository.ugm.ac.id/index.php?mod=penelitian detail\&sub $=$ PenelitianDetail\&act $=$ view\&typ $=$ html\&buku_i $\mathrm{d}=237585$ Juni 2016 .

Raco, J. R. (2010). Metode penelitian kualitatif: Jenis, karakteristik, dan keunggulannya. Jakarta: Grasindo.

Rusch, N., Evans-Lacko, S., Henderson, C., Flach, C., \& Thornicroft, G. (2011). Knowledge and attitude as predictors of intentions to seek help for and disclose a mental illness. Psychiatric Services, 62(6), 675-678.

Septa, D. \& Khoiri, N. (2010). Wayang sebagai media pembelajaran fisika untuk meningkatkan hasil belajar siswa pada pokok bahasan getaran dan gelombang pada siswa kelas VIII SMP Purnama 1 Semarang. JP2F, 1(1), 1-7.

Simamora, R. H. (2009). Buku ajar pendidikan dalam keperawatan. Jakarta: EGC.

Strauss, A. \& Corbin, J. (2013). Dasar-dasar penelitian kualitatif (tata langkah dan teknik-teknik teoritisasi data). Yogyakarta: Pustaka Pelajar.

Subandi, M.A. (2012). Agama dalam perjalanan gangguan mental psikotik dalam konteks budaya Jawa. Jurnal Psikologi, 39(2), 167-179

Sugiyono. (2014). Metode penelitian pendidikan (pendekatan kuantitatif, kualitatif, dan R\&D). Bandung: Alfabeta.

Suhardana, K. (2010). Karmaphala: Menciptakan karma baik menurut kitab suci Hindu. Surabaya: Paramita.

Suparno, P. (2008). Riset tindakan untuk pendidik. Jakarta: Grasindo.

Suriyani, L. D. (2016 Februari). 20 tahun terkurung di balik gerbang. Diakses dari: https://beritagar.id/artikel/laporan-khas/20tahun-terkurung-di-balik-gerbang 6 Oktober 2016.

Sutardi, T. (2007). Antropologi: Mengungkap keragaman budaya. Bandung: PT Setia Purnama Inves.

Sutika, I. K. (2014 September). Pemprov Bali perhatian pada penderita pangguan jiwa. Diakses dari: http://bali.antaranews.com/berita/59728/pemprov-baliperhatian-pada-penderita-gangguan-jiwa 30 September 2016.

Syaharia, A. R. H. (2009). Stigma gangguan jiwa perspektif kesehatan mental Islam. Diunduh dari: http://digilib.uinsuka.ac.id/1708/ 26 September 2016.
Taylor, S. E., Peplau, L. A., \& Sears, D. O. (2009). Psikologi sosial edisi kedua belas. Jakarta: Kencana.

Thong, D. (2011). Memanusiakan manusia: Menata jiwa membangun bangsa. Jakarta: PT Gramedia Pustaka Utama.

Yuniarto, B. (2013). Membangun kesadaran warga negara dalam pelestarian lingkungan. Yogyakarta: Deepublish.

Yusuf, A., Tristiana, D., Nihayati, H. E., Fitryasari, R. \& Hilfida, N. H. (2016). Stigma keluarga pasien gangguan jiwa skizofrenia. Diunduh dari: https://www.researchgate.net/publication/311910653_Stig ma_Keluarga_Pasien_Gangguan_Jiwa_Skizofrenia 20 Mei $20 \overline{17}$.

Yusuf, A.M. (2014). Metode penelitian: Kuantitatif, kualitatif, dan penelitian gabungan. Jakarta: Prenadamedia Group. 


\section{LAMPIRAN}

Tabel 1

Waktu Pelaksanaan, Kode Data Rekaman, Verbatim dan Observasi

\begin{tabular}{|c|c|c|c|c|c|}
\hline 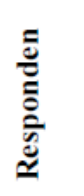 & 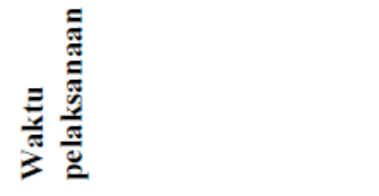 & $\overline{\bar{w}}$ & 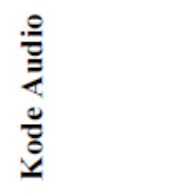 & 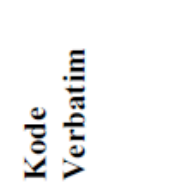 & 冚 \\
\hline GM & Minggu, 8 Januari 2017 & 35 Menit 08 Detik & AU-GM01 & VB-GM01 & FN-GM01 \\
\hline $\mathrm{SA}$ & $\begin{array}{l}\text { Jumat, } 4 \text { November } 2016 \\
\text { Jumat, } 6 \text { Januari } 2017\end{array}$ & $\begin{array}{l}57 \text { Menit19 Detik } \\
41 \text { Menit } 56 \text { Detik }\end{array}$ & $\begin{array}{l}\text { AU-SA01 } \\
\text { AU-SA02 }\end{array}$ & $\begin{array}{l}\text { VB-SA01 } \\
\text { VB-SA02 }\end{array}$ & $\begin{array}{l}\text { FN-SA01 } \\
\text { FN-SA02 }\end{array}$ \\
\hline YT & Jumat, 2 Desember 2016 & 43 Menit 20 Detik & AU-YT01 & VB-YT01 & FN-YT01 \\
\hline $\mathrm{AN}$ & Kamis, 17 November 2016 & 34 menit 14 detik & AU-AN01 & VB-AN01 & FN-AN01 \\
\hline LS & Rabu, 2 November 2016 & 48 menit 8 detik & AU-LS01 & VB-LS01 & FN-LS01 \\
\hline MW & Kamis, 13 Oktober 2016 & 24 menit 15 detik & AU-MW01 & VB-MW01 & FN-MW01 \\
\hline $\mathrm{AR}$ & Rabu, 12 Oktober 2016 & 31 Menit 17 Detik & AU-AR01 & VB-AR01 & FN-AR01 \\
\hline
\end{tabular}


Tabel 2

Kearifan Lokal Masyarakat Bali

\begin{tabular}{|c|c|c|c|c|}
\hline & \multicolumn{4}{|c|}{ Bentuk Penerapan Kearifan Lokal } \\
\hline & Karma phala & Tat twam asi & Tri pramana & $\begin{array}{c}\text { Tri kaya } \\
\text { parisudha }\end{array}$ \\
\hline $\begin{array}{c}\text { Pengaruh } \\
\text { terhadap Stigma }\end{array}$ & $\begin{array}{l}\text { Mengurangi } \\
\text { dan } \\
\text { membentuk } \\
\text { stigma }\end{array}$ & $\begin{array}{l}\text { Mengurangi } \\
\text { stigma }\end{array}$ & $\begin{array}{l}\text { Mengurangi } \\
\text { stigma }\end{array}$ & $\begin{array}{l}\text { Mengurangi } \\
\text { stigma }\end{array}$ \\
\hline
\end{tabular}


Tabel 3

Bentuk Penerapan Kearifan Lokal

Bentuk Penerapan Kearifan Lokal

\begin{tabular}{|c|c|c|c|}
\hline & Isi & ina & $a$ \\
\hline $\begin{array}{l}\text { Perilaku tidak } \\
\text { mencemooh } \\
\text { ODGJ yang } \\
\text { ditunjukkan } \\
\text { masyarakat Bali } \\
\text { karena } \\
\text { masyarakat Bali } \\
\text { memercayai } \\
\text { bahwa apabila } \\
\text { masyarakat Bali } \\
\text { mencemooh } \\
\text { ODGJ maka di } \\
\text { suatu hari nanti } \\
\text { masyarakat Bali } \\
\text { akan } \\
\text { mendapatkan } \\
\text { cemoohan } \\
\text { maupun } \\
\text { kepercayaan } \\
\text { seperti akan } \\
\text { terkena } \\
\text { gangguan jiwa di } \\
\text { suatu hari nanti } \\
\text { apabila } \\
\text { memberikan } \\
\text { cemoohan } \\
\text { kepada ODGJ }\end{array}$ & $\begin{array}{l}\text { Tercermin dalam sikap } \\
\text { masyarakat yang tidak } \\
\text { mencemooh ODGJ } \\
\text { karena masyarakat Bali } \\
\text { merefleksikan hal } \\
\text { tersebut ke dalam dirinya } \\
\text { sendiri. Responden } \\
\text { memiliki pikiran seperti } \\
\text { bagaimana kalau } \\
\text { responden yang sakit } \\
\text { seperti itu, bagaimana } \\
\text { kalau saudara responden } \\
\text { yang seperti itu, seperti } \\
\text { apa kelakuan responden } \\
\text { saat responden sakit } \\
\text { seperti itu, dan apa yang } \\
\text { bisa responden lakukan } \\
\text { untuk keluarganya kalau } \\
\text { keluarga responden } \\
\text { mengalami sakit seperti } \\
\text { itu. Pikiran-pikiran } \\
\text { seperti inilah yang } \\
\text { kemudian menjadikan } \\
\text { landasan masyarakat } \\
\text { Bali untuk tidak } \\
\text { memberikan stigma } \\
\text { terhadap ODGJ. }\end{array}$ & 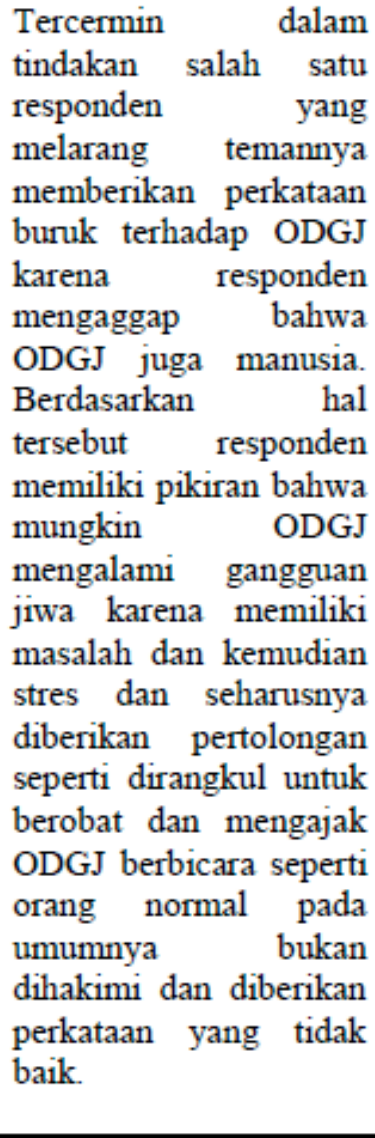 & $\begin{array}{l}\text { Berpikir yang baik tercermin } \\
\text { dari tindakan memandang } \\
\text { orang lain sebagai bagian dari } \\
\text { kehidupan masyarakat dan } \\
\text { selalu berpikiran positif } \\
\text { terhadap suatu hal misalnya } \\
\text { ketika ODGJ datang mendekat, } \\
\text { dengan berpikir yang baik } \\
\text { masyarakat akan menganggap } \\
\text { bahwa ODGJ itu orang yang } \\
\text { sedang sakit sehingga tidak } \\
\text { perlu takut dan mengusir. } \\
\text { Berkata yang baik dapat } \\
\text { tercermin dari perilaku } \\
\text { menyapa ODGJ, mengajak } \\
\text { ODGJ berkomunikasi secara } \\
\text { normal bukan mencela maupun } \\
\text { mencemooh ODGJ. } \\
\text { Berperilaku yang baik } \\
\text { tercermin dalam perilaku } \\
\text { merangkul ODGJ, memberikan } \\
\text { perawatan, memberikan kasih } \\
\text { sayang, dan memberikan } \\
\text { bantuan instrumental bukan } \\
\text { berupa perilaku kekerasan dan } \\
\text { juga diskriminasi. }\end{array}$ \\
\hline
\end{tabular}


Tabel 4

Persepsi Masyarakat Terkait ODGJ

\begin{tabular}{|c|c|c|c|c|}
\hline Ciri fisik & Penyebab & & Labeling & Stereotip \\
\hline $\begin{array}{l}\text { Berperilaku, } \\
\text { berpikir, berbicara } \\
\text { tidak normal, } \\
\text { berpenampilan } \\
\text { tidak terawat }\end{array}$ & $\begin{array}{l}\text { Penyebab } \\
\text { medis dan } \\
\text { medis }\end{array}$ & $\begin{array}{c}\text { secara } \\
\text { non- }\end{array}$ & $\begin{array}{l}\text { Orang stress, gila, } \\
\text { orang sakit, buduh, } \\
\text { tidak waras }\end{array}$ & $\begin{array}{l}\text { Orang yang berada } \\
\text { dipinggir jalan, } \\
\text { berpenampilan } \\
\text { kumal, tidak dapat } \\
\text { mengingat identitas } \\
\text { diri, tidak dapat } \\
\text { disembuhkan, dan } \\
\text { agresif } \\
\text { mengganggu } \\
\text { keamanan }\end{array}$ \\
\hline
\end{tabular}

Tabel 5

Perlakuan Terhadap ODGJ 


\section{Perlakuan positif}

\section{Perlakuan negatif}

Perilaku merangkul ODGJ, mencari tahu sikap tidak ingin melibatkan diri terlalu faktor penyebab gangguan jiwa, memberi jauh, cuek, tidak berani mendekat dan bantuan instrumental, memberi saran diskriminasi pengobatan, menghadirkan rasa aman dan percaya pada diri, memberi kesejukan, mempercayakan tanggung jawab pekerjaan, menunjukan rasa prihatin, menghargai, memberi kedamaian, memberi perhatian dan kasih sayang, memperlakukan sesuai etika, dan memberi pengobatan. 